\title{
Temperature Effects in Anaerobic Digestion Modeling
}

\author{
Wenche Hennie Bergland Carlos Dinamarca Rune Bakke \\ Department of Process, Energy and Environmental Technology, Telemark University College, Norway, \\ Wenche.Bergland@hit.no, Carlos.Dinamarca@hit.no, Rune.Bakke@hit.no
}

\begin{abstract}
Temperature effects on kinetic coefficients for the biochemical processes particle disintegration, hydrolysis and substrate uptake reactions were included in the anaerobic digestion model 1 (ADM1). It was evaluated on data from a pilot experiments in a 220 liter $\mathrm{AD}$ sludge bed reactor treating diary manure for 4 months of varying loads and temperatures; 25,30 and $35{ }^{\circ} \mathrm{C}$. Implementing individual temperature effects for each biochemical reaction gave the best fit for both biogas production and intermediate products. Simulated overall soluble and particulate organic carbon removal, $\mathrm{pH}$ and acetate are close to measured values while propionate is underestimated. Temperature has a moderate influence on steady state biogas production in sludge bed $\mathrm{AD}\left(1.6 \%\right.$ per degree at $30-35^{\circ} \mathrm{C}$ and 3.4 $\%$ per degree at $25-30{ }^{\circ} \mathrm{C}$ ), implying the net energy gain can peak at $\mathrm{T}<35^{\circ} \mathrm{C}$ in some cases.
\end{abstract}

Keywords: Anaerobic digestion, sludge bed, temperature dependence, ADMI.

\section{Introduction}

Anaerobic digestion (AD) can be used to recover energy as methane from organic wastes and thereby reduce greenhouse gas emissions by contributing to more sustainable waste handling.

Anaerobic degradation of organic matter into biogas is carried out by a consortium of microorganisms, which degrade complex organic macro-molecules by extracellular (disintegration, hydrolysis) and intracellular (acidogenesis, acetogenesis, methanogenesis) enzyme mediated biochemical reactions (Fig. 1). The Anaerobic Digestion Model No.1 (ADM1) (Batstone et al., 2002) is a common platform of modelling, simulations and understanding AD. It was developed by the International Water Association (IWA).

ADM1 was developed primarily to model digestion of sludge from wastewater treatment plants where the standard process temperatures are $35{ }^{\circ} \mathrm{C}$, or $55^{\circ} \mathrm{C}$, presumed optimal for respectively meso- and thermophilic digestion. Energy optimized AD may, however, not be such, e.g. $35^{\circ} \mathrm{C}$ for mesophilic. Higher temperatures $\left(35-42{ }^{\circ} \mathrm{C}\right)$ are sometimes preferred while lower digestion temperature than microbial optima for which standard model parameters are available may also be favorable in some cases. Anaerobic reactors fed with low energy substrates, such as cow manure slurry, can possibly be an example of the latter since a large portion of the potential energy might be required to heat the reactor to $35{ }^{\circ} \mathrm{C}$ in cold climates. The potential for reducing heating requirements is therefore examined by testing and modeling $\mathrm{AD}$ at temperatures lower than 35 ${ }^{\circ} \mathrm{C}$ claimed to be the mesophilic optimum (Lin et al., 1987)

ADM1 contains several biochemical reactions, physiochemical equilibriums and gas-liquid transfer processes which all are affected by temperature. Increased knowledge about $\mathrm{AD}$ process parameters temperature dependency is generally required for adequate $\mathrm{AD}$ modeling using the standard ADM1 at temperatures other than $35^{\circ} \mathrm{C}$.

Temperature effects on the biogas production is known (Henze and Harremoës, 1983) but the effects on individual kinetic coefficients for particle disintegration, hydrolysis and substrate uptake reactions might be required to adequately simulate $\mathrm{AD}$ with both particulate and dissolved organics in the substrate where it is not known which is the rate-limiting reaction.

Temperature dependency for the kinetics in $\mathrm{AD}$ is often described using one Arrhenius equation (Banik et al., 1998; Grant and Lin 1995; Kettunen and Rintala,1997) for exponential growth in the mesophilic area up to $30{ }^{\circ} \mathrm{C}$, but in order to include both the opposing synthesis and degradation processes the temperature dependency for the biochemical reactions in the whole mesophilic range should be modelled using double Arrhenius equations (1) (Hinshelwood, 1946; Pavlostathis and Giraldo-Gomez, 1991).

$$
\rho=A_{1} \exp \left(\frac{-E_{a 1}}{R T}\right)-A_{2} \exp \left(\frac{-E_{a 2}}{R T}\right)
$$

$\rho=$ microbial activity, $A$ is the frequency factor, $E_{a}$ is the apparent activation energy, $\mathrm{R}$ is the gas constant and $\mathrm{T}$ is the absolute temperature.

This temperature effect on each individual degradation reaction are studied to some degree (Donoso-Bravo et al., 2009; Rebac et al., 1995, Lin et al., 1987) but by using varying models for the temperature effect. Intermediate products are measured here to evaluate the model's ability to simulate individual degradation reaction. 
It is probably sufficient that the rate limiting degradation step is modeled utilizing the proper temperature effect(s). It is however not always obvious what the rate-limiting step is. Hydrolysis and disintegration are often assumed rate limiting for particle rich substrates, such as manure, but this may be altered by pre-treatment. Particle rich manure filtrate, for which the rate-limiting step is unknown, is used as feed in this study.

Modelling $\mathrm{AD}$ at thermophilic $\left(45-70{ }^{\circ} \mathrm{C}\right)$ and psychrophilic $\left(4-15^{\circ} \mathrm{C}\right)$ temperatures with possible other degradation paths (Vavilin et al., 1997) is not attempted here. Temperature effects on diffusion are assumed insignificant in the range investigated.

An intention is that the model can be used to reveal optimal sludge bed $\mathrm{AD}$ temperatures, such as to investigate the potential for reducing heating requirements by reactor operation at temperatures below $35^{\circ} \mathrm{C}$.

The purpose of this study is to quantify temperature effects on AD modelling by establishing and testing an extended ADM1 ("ADM1-T") to account for temperature effects on model parameters.

The model is tested on data from a 220 liter $A D$ sludge bed reactor treating diary manure filtrate for 4 months of varying loads and with step temperature changes between 25,30 and $35^{\circ} \mathrm{C}$.

Additional aims are:

(1) Distinguish between physical and biological effects of temperature;

(2) Evaluate temperature effects in sludge bed $\mathrm{AD}$ and

(3) Look for limiting reaction steps for process capacity by testing and modeling $\mathrm{AD}$ at different loads and temperatures.

This should improve our general understanding of how, where and when temperature influences AD processes.

\section{Materials and Methods}

Temperature dependent kinetic parameters for both biochemical and physico-chemical processes are retrieved from literature survey. Other relevant model parameters are retrieved from batch tests and compared against continuous $\mathrm{AD}$ using diary manure filtrate.

\subsection{Model Parameters}

\subsubsection{Biochemical kinetic parameters}

Kinetic temperature dependent parameters for biochemical processes in ADM1-T are $\mathrm{K}_{\mathrm{dis}}, \mathrm{K}_{\mathrm{hyd}}, \mathrm{k}_{\mathrm{m}}$, $\mathrm{K}_{\mathrm{d}}, \mathrm{Y}$ and $\mathrm{K}_{\mathrm{S}}$, which are recommended in ADM1 for 35 ${ }^{\circ} \mathrm{C}$ and used as a reference (Table 1 ). $\mathrm{K}_{\text {dis }}$ and $\mathrm{K}_{\text {hyd }}$ are for 1.st order extracellular reactions disintegration and hydrolysis (2).

$$
\rho=k_{d i s, h y d} \cdot X_{d i s, h y d}
$$

$\rho=$ disintegration rate or hydrolysis rate of solid substrate $\left(\mathrm{kg}\right.$ COD solid substrate $\mathrm{m}^{-3} \mathrm{~d}^{-1}$ where COD $=$ chemical oxygen demand), $\mathrm{X}_{\text {dis, hyd }}=$ solid substrate concentration $\left(\mathrm{kg}\right.$ COD solid substrate $\left.\mathrm{m}^{-3}\right), \mathrm{K}_{\text {dis,hyd }}=$ temperature dependent kinetic parameter for disintegration or hydrolysis $\left(\mathrm{d}^{-1}\right)$. Disintegration is typically considered the rate-limiting step for substrates containing mainly particles, while hydrolysis of proteins, lipids and carbohydrates is the rate limiting in high rate digesters and then only disintegration of decaying microorganisms is accounted for (Batstone et al., 2002).

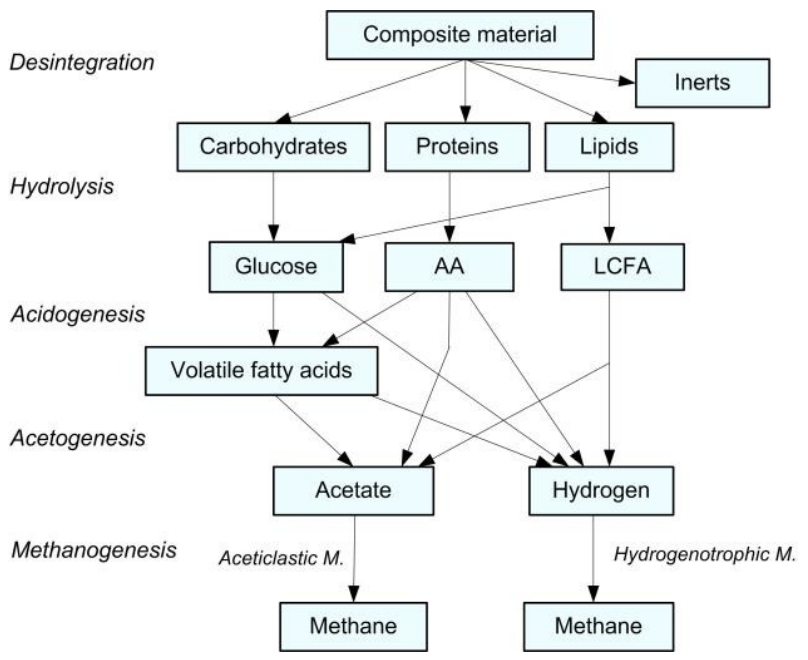

Figure 1. COD flow diagram of the Anaerobic Digestion Model No.1 (Adapted from Batstone et al., 2002) showing the biochemical reactions for which temperature effects have been included as arrows.

Each intracellular enzyme mediated biochemical reaction (acidogenesis, acetogenesis, methanogenesis) (Fig. 1) is generally approximated by a Monod type saturation function where the reaction rate of substrate uptake by organism, $\rho\left(\mathrm{kg}\right.$ COD substrate $\left.\mathrm{m}^{-3} \mathrm{~d}^{-1}\right)$, can be described as:

$$
\rho=k_{m} \cdot \mathrm{X} \cdot \frac{S}{\mathrm{~S}+K_{s}} \cdot \mathrm{I}
$$

Equation (3) contains the maximum substrate uptake rate constant $\mathrm{k}_{\mathrm{m}}\left(\mathrm{kg}\right.$ COD substrate $\mathrm{kg}$ COD biomass ${ }^{-1}$ $\left.\mathrm{d}^{-1}\right), \mathrm{X}=$ biomass concentration ( $\mathrm{kg}$ COD biomass $\mathrm{m}^{-3}$ ), $\mathrm{S}=$ substrate concentration ( $\mathrm{kg}$ COD substrate $\mathrm{m}^{-3}$ ), $\mathrm{K}_{\mathrm{S}}$ $=$ half saturation constant $\left(\mathrm{kg}\right.$ COD substrate $\left.\mathrm{m}^{-3}\right)$ and I $=$ inhibition factor. The growth of biomass, $\mathrm{X}$, is expressed through the yield, Y ( $\mathrm{kg}$ COD biomass X kg${ }^{1}$ COD substrate) of uptake of substrate, while biomass death is described by $\mathrm{K}_{\mathrm{d}}\left(\mathrm{d}^{-1}\right)$ (Table 1$)$.

Temperature effects on $K_{h y d}$ and $k_{m}$ are retrieved from literature sources. The hydrolysis kinetic parameter is also tested by a set of laboratory experiments to find both the $\mathrm{k}_{\text {hyd }}$ for this substrate and the effect of low temperature. A Hinshelwood double 
Arrhenius function is recommended (Batstone et al., 2002) as the temperature dependency for the biochemical reactions expressed through $\mathrm{k}_{\mathrm{m}}$. The affinity for the substrate parameter $\mathrm{K}_{\mathrm{S}}$ is therefore not altered. Monod (1949) assumes a saturation relationship between substrate concentration and growth rate while growth yield remained constant over a wide range of substrate concentrations that requires a constant $\mathrm{K}_{\mathrm{S}}$. We extend this assumption to temperature and evaluate if temperature effects on yield can be ignored. The death of biomass $\mathrm{K}_{\mathrm{d}}$ has a constant small value in ADM1. The temperature effect, if any, is assumed small and not altered.

Table 1 Biochemical processes temperature dependent kinetic parameters.

\begin{tabular}{|c|c|c|c|}
\hline Parameter & Biochemical & $\begin{array}{l}\text { Expre } \\
\text { ssion }\end{array}$ & Denomination \\
\hline $\mathrm{K}_{\mathrm{dis}}$ & disintegration & 2 & $\mathrm{~d}^{-1}$ \\
\hline $\mathrm{K}_{\text {hyd }}$ & hydrolysis & 2 & $\mathrm{~d}^{-1}$ \\
\hline $\mathrm{k}_{\mathrm{m}}$ & $\begin{array}{c}\text { max substrate } \\
\text { uptake rate } \\
\text { constant }\end{array}$ & 3 & $\begin{array}{c}\text { kg COD } \\
\text { substrate } \\
\mathrm{m}^{-3} \mathrm{~d}^{-1} \\
\end{array}$ \\
\hline $\mathrm{K}_{\mathrm{S}}$ & $\begin{array}{l}\text { half saturation } \\
\text { constant }\end{array}$ & 3 & $\begin{array}{c}\mathrm{kg} \text { COD } \\
\text { substrate } \mathrm{m}^{-3}\end{array}$ \\
\hline $\mathrm{Y}$ & $\begin{array}{c}\text { biomass } \\
\text { growth yield }\end{array}$ & & $\begin{array}{c}\mathrm{kg} \text { COD } \\
\text { biomass } \\
\mathrm{kg}^{-1} \mathrm{COD} \\
\text { substrate }\end{array}$ \\
\hline $\mathrm{K}_{\mathrm{d}}$ & $\begin{array}{l}\text { death rate of } \\
\text { biomass }\end{array}$ & & $\mathrm{d}^{-1}$ \\
\hline
\end{tabular}

Relative factors of the relevant temperatures, 35,30 and $25{ }^{\circ} \mathrm{C}$ are calculated from reported temperature effect (Henze and Harremoës, 1983) on the overall biogas production (Table 2). These factors are applied for all the kinetic parameters $\mathrm{K}_{\mathrm{dis}}, \mathrm{K}_{\mathrm{hyd}}$ and $\mathrm{k}_{\mathrm{m}}$ for all the degradation steps since the limiting reaction is unknown as a first approach.

Table 2. Relative temperature factors for kinetic parameters for the overall biogas production. Calculated from Henze and Harremoës (1983).

\begin{tabular}{|l|l|l|l|}
\hline Temperature $\left({ }^{\circ} \mathrm{C}\right)$ & 25 & 30 & 35 \\
\hline Temperature factor & 0.42 & 0.87 & 1 \\
\hline
\end{tabular}

Temperature effects on the kinetic parameters that are different for each degradation equation are also implemented. Relative temperature effects for hydrolysis, acidogenesis and acidoclastic methanogenesis of respectively starch, glucose and acetic acid through batch tests at $15-45{ }^{\circ} \mathrm{C}$ (DonosoBravo et al., 2009) is used to calculate temperature factors for each reaction (Table 3). Relative temperature effects on individual reactions are also reported by Rebac et al. (1995) for butyrate, propionate and acetate degraders at $10-40{ }^{\circ} \mathrm{C}$. Calculated relative factors from these temperature effects are also in Table 3. Reactions that were not found were estimated by using factors from "nearby" reactions in Fig. 1: The same temperature effect as for sugar uptake is used on amino acids and fatty acids uptake. The same temperature effect for hydrogen uptake as for acetate uptake is also used.

Table 3. Relative change of the kinetic parameters $K_{\text {dis, }}$ $\mathrm{K}_{\text {hyd }}$ and $\mathrm{k}_{\mathrm{m}}$ with temperature. Calculated from reported data in (A) Donoso-Bravo et al. (2009), and (B) Rebac et al. (1995).

\begin{tabular}{|c|c|c|c|c|}
\hline \multirow[t]{2}{*}{ Process } & \multicolumn{3}{|c|}{ Temperature $\left({ }^{\circ} \mathrm{C}\right)$} & \multirow[t]{2}{*}{ Ref. } \\
\hline & 25 & 30 & 35 & \\
\hline $\begin{array}{c}\text { Disintegration, } \\
\mathrm{K}_{\mathrm{dis}}\end{array}$ & \multicolumn{3}{|c|}{$\begin{array}{c}\text { Same as for hydrolysis } \\
\text { of carbohydrates }\end{array}$} & \\
\hline $\begin{array}{c}\text { Hydrolysis of } \\
\text { carbohydrates, } \\
\mathrm{K}_{\mathrm{hyd}, \mathrm{su}}\end{array}$ & 0.48 & 0.74 & 1.00 & $\mathrm{~A}$ \\
\hline $\begin{array}{l}\text { Hydrolysis of } \\
\text { protein, } K_{h y d, p r}\end{array}$ & \multicolumn{3}{|c|}{$\begin{array}{c}\text { Same as for hydrolysis } \\
\text { of carbohydrates }\end{array}$} & \\
\hline $\begin{array}{l}\text { Hydrolysis of lipids, } \\
\mathrm{K}_{\mathrm{hyd}, \mathrm{li}}\end{array}$ & \multicolumn{3}{|c|}{$\begin{array}{c}\text { Same as for hydrolysis } \\
\text { of carbohydrates }\end{array}$} & \\
\hline $\begin{array}{c}\text { Sugar } \\
\text { Uptake, } \mathrm{k}_{\mathrm{m}}\end{array}$ & 0.21 & 0.22 & 1.00 & A \\
\hline $\begin{array}{c}\text { Amino acid uptake, } \\
\mathrm{k}_{\mathrm{m}}\end{array}$ & \multicolumn{3}{|c|}{$\begin{array}{c}\text { Same as for sugar } \\
\text { uptake }\end{array}$} & \\
\hline Fatty acid uptake, $\mathrm{k}_{\mathrm{m}}$ & \multicolumn{3}{|c|}{$\begin{array}{c}\text { Same as for sugar } \\
\text { uptake }\end{array}$} & \\
\hline Butyrate uptake, $\mathrm{k}_{\mathrm{m}}$ & 0.67 & 0.86 & 1.00 & $\mathrm{~B}$ \\
\hline Propionate uptake & 0.70 & 0.90 & 1.00 & $\mathrm{~B}$ \\
\hline $\begin{array}{c}\text { Aceticlastic } \\
\text { methanogens, } \mathrm{k}_{\mathrm{m}}\end{array}$ & 0.69 & 0.93 & 1.00 & A \\
\hline $\begin{array}{c}\text { Aceticlastic } \\
\text { methanogens, } \mathrm{k}_{\mathrm{m}}\end{array}$ & 0.48 & 0.70 & 1.00 & B \\
\hline $\begin{array}{l}\text { Hydrogenotroph } \\
\text { methanogens, } \mathrm{k}_{\mathrm{m}}\end{array}$ & \multicolumn{3}{|c|}{$\begin{array}{c}\text { Same as for aceticlastic } \\
\text { methanogens }\end{array}$} & \\
\hline
\end{tabular}

Three different simulations were done;

$\mathrm{H}$ : using the same temperature effect (Table 2) for all the degradation steps.

D: using all the temperature effects from Table 3 but with methanogenesis from Donoso-Bravo et al. (2009)

$\mathrm{R}$ : using all the temperature effects from Table 3 but with methanogenesis from Rebac et al. (1995)

\subsubsection{Physio-chemical parameters}

The temperature dependencies of the temperature dependent kinetic parameters $\mathrm{k}_{\mathrm{a}}$ and $\mathrm{k}_{\mathrm{H}}$ (Table 4) are in the standard ADM1 while the temperature dependency of the mass transfer coefficient $\mathrm{k}_{\mathrm{L}} \mathrm{a}$ is implemented here.

Physico-chemical equilibrium is modeled based on the law of mass action for aqueous substances and on Henry's law to model the solubility of a gas in water. Both are temperature dependent; which are given by equations (4) and (5) respectively. 


$$
\begin{gathered}
k_{a}=\frac{\left[B^{-}\right] \cdot\left[H^{+}\right]}{\left[S_{\text {total }}\right]-\left[S_{\text {ion }}\right]} \\
S_{\text {total }}=k_{H} \cdot P
\end{gathered}
$$

Where both $\mathrm{K}_{\mathrm{a}}$ and $\mathrm{k}_{\mathrm{H}}$ are temperature dependent according to van Hoff's equation (Eq. 6).

$$
\ln \frac{k_{2}}{k_{1}}=\frac{\Delta H^{\circ}}{R} \cdot\left(\frac{1}{T_{1}}-\frac{1}{T_{2}}\right)
$$

The equilibriums reactions (7-9) have temperature correction implemented while carboxylic acids (10) temperature dependency is assumed small and not taken into account (Batstone et al., 2002).

$$
\begin{aligned}
& \mathrm{CO}_{2}+\mathrm{H}_{2} \mathrm{O} \leftrightarrow \mathrm{HCO}_{3}^{-}+\mathrm{H}^{+} \\
& \mathrm{NH}_{4}{ }^{+}+\mathrm{H}_{2} \mathrm{O} \leftrightarrow \mathrm{NH}_{3}+\mathrm{H}^{+} \\
& \mathrm{H}_{2} \mathrm{O} \leftrightarrow \mathrm{H}^{+}+\mathrm{OH}^{-} \\
& \mathrm{R}-\mathrm{COOH} \leftrightarrow \mathrm{R}_{-} \mathrm{COO}^{-}+\mathrm{H}^{+}
\end{aligned}
$$

Dynamic gas transfer is also dependent on temperature, accounted for by the temperature dependency of the overall mass transfer coefficient, $\mathrm{k}_{\mathrm{L}} \mathrm{a}$ (Eq.11), according to Saravanan et al. (2000).

$$
\mathrm{k}_{\mathrm{La}}=0.56 \cdot \mathrm{T}+27.9
$$

Table 4. Temperature dependent physico-chemical processes parameters.

\begin{tabular}{||l|l|l|}
\hline Parameter & $\begin{array}{l}\text { Physico- } \\
\text { chemical }\end{array}$ & $\begin{array}{l}\text { Expression } \\
\text { in Equations }\end{array}$ \\
\hline $\mathrm{k}_{\mathrm{a}}$ & $\begin{array}{l}\text { Equilibrium } \\
\text { constant }\end{array}$ & $(4)$ \\
\hline $\mathrm{k}_{\mathrm{H}}$ & Henry's constant & $(5)$ \\
\hline $\mathrm{k}_{\mathrm{L}} \mathrm{a}$ & $\begin{array}{l}\text { Mass transfer } \\
\text { coefficient }\end{array}$ & $(11)$ \\
\hline
\end{tabular}

\subsubsection{Non temperature dependent parameters}

The conditions with longer sludge retention time (SRT) than hydraulic retention time (HRT) is implemented in ADM1 as SRT $=$ tres_ $\mathrm{x}+\mathrm{HRT}$, recommended with tres_x $=40$ days for high rate, sludge bed reactors. The validation experiment was carried out in a sludge bed reactor, but not at high rate, so lower tres_x is also evaluated.

ADM1 uses the same fixed stoichiometry to model product distribution for 35 and $55^{\circ} \mathrm{C}$. These stoichiometric values where assumed appropriate for the range from 25 to $35^{\circ} \mathrm{C}$ also.

\subsection{Biodegradability and hydrolysis}

Long-term batch tests using $100 \mathrm{ml}$ medical syringes as batch reactors were performed on diary manure filtrate at room temperature $\left(\sim 23{ }^{\circ} \mathrm{C}\right)$ and at $35^{\circ} \mathrm{C}$ to determine the biodegradable amount and the kinetic hydrolysis parameter for this substrate. $30 \mathrm{ml}$ of manure filtrate was added to the syringe and the gas production was monitored regularly. The soluble and total chemical oxygen demand, $\mathrm{COD}_{\mathrm{S}}$ and $\mathrm{COD}_{\mathrm{T}}$, (representing the energy content of the waste) was measured before and after the test. The not degradable fraction of the substrate was calculated based on remaining COD. The $\mathrm{COD}_{\mathrm{T}}$ removed is equivalent to the biogas potential. To determine how much of the COD came from either the soluble $\left(\mathrm{B}_{0 \text { soluble }}\right)$ or the solid ( $\left.\mathrm{B}_{\text {0particle }}\right)$ fractions, a factor $\mathrm{f}=\mathrm{B}_{\text {0soluble }} / \mathrm{B}_{0 \text { particle }}$ was estimated by COD particle and liquid contents at start and end of the experiment.

The hydrolysis kinetic factor $\mathrm{K}_{\mathrm{h}}$ was calculated using:

$$
\mathrm{B}=\mathrm{B}_{0}\left(1-\mathrm{e}^{-\mathrm{kt}}\right)
$$

at temperatures 23 and $35{ }^{\circ} \mathrm{C}$. $\mathrm{B}_{0}$ is the total biogas production and $\mathrm{B}$ is the biogas production at the given time t.

\subsection{AD sludge bed experiment}

\subsubsection{AD reactor design operation}

The diary manure feed was from the organic milk producer Foss Farm in Skien, Norway. The cattle were fed grass and clover ensilage and $25 \%$ "dairy concentrate" (19\% protein). The manure was flushed into an indoor temporarily storage tank, diluting the manure with flush water by $14 \%$ on average (Bergland et al., 2014). The manure was stored for 1-6 weeks in the storage tank before treated in a rotating vacuum drum filter (mesh light opening of $1.4 \mathrm{~mm}$ ) to remove the coarse solids. The filtrate was used as AD feed (substrate) in this study.

The diary manure AD was performed in a sludge bed reactor as an integral part of a process to generate fertilizers and biogas, as described by Haugen et al. (2013) (Fig. 2).

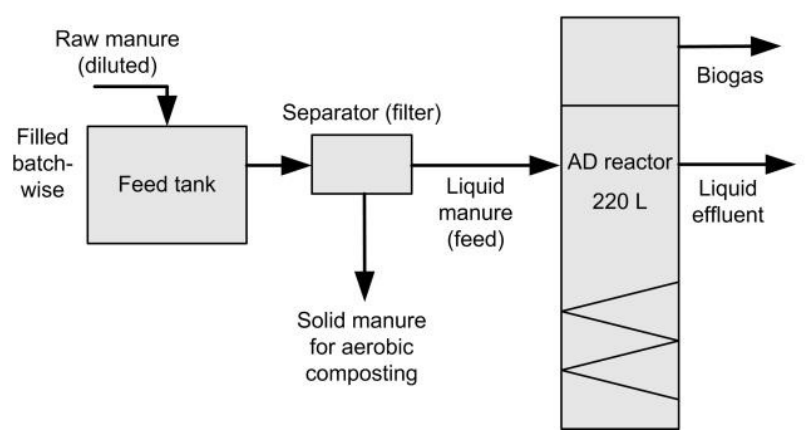

Figure 2. The sludge bed AD process of this pilot plant treating dairy cow manure was the subject of this study.

The AD reactor had a liquid volume of 254 liter with $400 \mathrm{~mm} \varnothing$ and $2000 \mathrm{~mm}$ height consisting mainly of a lower liquid volume for suspended biomass. A plastic support medium for biofilm growth was integrated with solids, gas and liquid separation at the top. The process 
had been operated for 2 year at $35^{\circ} \mathrm{C}$ following 70 days at $25{ }^{\circ} \mathrm{C}$ before the 130 days operation reported here allowing the culture to adapt to cow manure filtrate as substrate.

The reactor was operated at the mesophilic temperatures 25,30 and $35{ }^{\circ} \mathrm{C}$ during this test. The load was from zero up to a load corresponding to a hydraulic retention time (HRT) of 8.5 days. The reactor was semicontinuously operated by pulse feeding with the feeding pump controlled as a binary (On/Off) device.

\subsubsection{Monitoring and analysis}

A comprehensive online- and offline-testing scheme was used to monitor the $\mathrm{AD}$ reactor. Biogas production $\left(\mathrm{L} \mathrm{d}^{-1}\right)$, gas composition (fractions of $\mathrm{CO}_{2}$ and $\mathrm{CH}_{4}$ ), liquid flow and reactor temperature were monitored continuously online as described by Haugen et al. (2013). Substrate and effluent samples were collected 12 times a week. Total chemical oxygen demand $\left(\mathrm{COD}_{\mathrm{T}}\right)$, soluble COD (CODs), total solids (TS), volatile solids (VS), total suspended solids (TSS), volatile suspended solids (VSS), $\mathrm{pH}$, alkalinity, $\mathrm{NH}_{4}{ }^{+}-\mathrm{N}$ and VFA's (acetate, propionate, butyrate, iso-butyrate, valerate, iso-valerate) were analyzed as described in Bergland et al. (2015).

\section{Results}

\subsection{Biodegradability and hydrolysis input to the model}

The batch tests gave a total biodegradable fraction of 0.26 of the $\mathrm{COD}_{\mathrm{T}}$. The non-degradable is therefore 74 $\%$ for the manure substrate COD used. The fractions of protein, carbohydrates and lipids in the biodegradable fraction are set to 0.27 (f_pr), 0.51 (f_ch) and 0.22 (f_li) respectively (Table 6) as found for slurry cattle manure (Møller et al., 2003). Tests of the temperature dependency revealed that $96 \% \pm 2 \%$ of the biogas production at $35{ }^{\circ} \mathrm{C}$ were achieved at $23{ }^{\circ} \mathrm{C}$ in the batch tests, confirming that yields are quite insensitive to temperature. The effect is implemented as $96 \%$ at 25 ${ }^{\circ} \mathrm{C}$ and $98 \%$ at $30{ }^{\circ} \mathrm{C}$. The fraction of biodegradable from particles is below 0.38 and the rest from soluble organics, determined based on the COD contents before and after the batch test (Table 5). 0.3 is used as biodegradable fraction from particles and 0.7 from dissolved COD in the model.

Table 5. Diary manure filtrate parameters used to calculate the COD content of the degradable and nondegradable fractions of particulates and dissolved organics of the AD reactor substrate.

\begin{tabular}{|l|l|l|l|}
\hline Property & Before & After & $\triangle$ COD \\
\hline $\mathrm{COD}_{\mathrm{T}}$ & 50 & 37 & 13 \\
\hline $\mathrm{COD}_{\mathrm{S}}$ & 14 & 6 & 8 \\
\hline $\begin{array}{l}\mathrm{COD} \\
\mathrm{COD}\end{array} \mathrm{COD}_{\mathrm{S}}=$ & 36 & 31 & \\
\hline
\end{tabular}

Hydrolysis kinetics were also found from the batch test that lasted 91 days, excluding data from the first 23 weeks (when hydrolysis is not the rate-limiting step). Using least square method on Eq.12 (Chap 2.2) gives estimation of $k_{\text {hyd }}$ to be $0.13 \mathrm{~d}^{-1}$ at 35 and $0.05 \mathrm{~d}^{-1}$ at 23 ${ }^{\circ} \mathrm{C}$ (Fig. 3). This is in the range of $\mathrm{k}_{\text {hyd }}$ found for straw and grass tested by Veeken and Hamelers (1999) at temperatures $20-40{ }^{\circ} \mathrm{C}$.
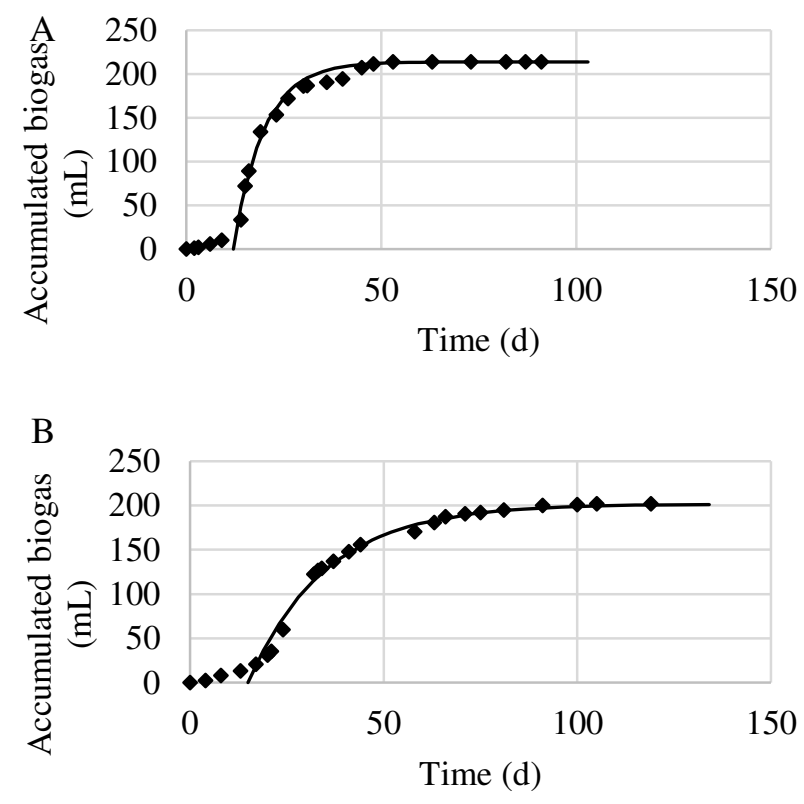

Figure 3. Batch test data and fitted line for $35^{\circ} \mathrm{C}(\mathrm{A})$ and $23{ }^{\circ} \mathrm{C}$ (B) used to calculate $\mathrm{k}_{\mathrm{hyd}}$.

The average hydrolysis factor for sludge is $\mathrm{k}_{\text {hyd }}=$ 0.183 at $35^{\circ} \mathrm{C}$ (Batstone et al., 2002). The $\mathrm{k}_{\text {hyd }}$ values for cow manure used here are therefor changed by multiplying the various coefficients for sludge with the factor $0.13 / 0.183$ at $35{ }^{\circ} \mathrm{C}$ to: $\mathrm{k}_{\text {hyd_ch }}=0.18$ from $0.25 \mathrm{~d}^{-}$ ${ }^{1}$, k kyd_li to 0.07 from 0.1 and khyd_pr to 0.14 from $0.2 \mathrm{~d}^{-1}$ for all the simulations. The $\mathrm{k}_{\mathrm{hyd}}$ values are similarly adjusted down for the lower temperatures with relative factors of 1 at $35{ }^{\circ} \mathrm{C}, 0.74$ at $30{ }^{\circ} \mathrm{C}$ and 0.47 at $25{ }^{\circ} \mathrm{C}$ which is almost identical to the temperature effect found by Donoso-Bravo et al. (2009) for carbohydrates (Table 3).

The batch results (Fig. 3) also confirms that temperature influence $\mathrm{AD}$ kinetics much more than stoichiometry ( $\mathrm{k}_{\text {hyd }}$ is reduced by $60 \%$ while yield by 4 $\%$ at $23{ }^{\circ} \mathrm{C}$ compared to at $35^{\circ} \mathrm{C}$ ).

\subsection{AD sludge bed reactor data input to the model}

The biogas production and effluent concentrations of the pilot $\mathrm{AD}$ are presented with the simulated results in Figure 5 - 6 during the given load and temperature step changes (Fig. 4). Some scattering in measured AD substrate composition may be due to real, uncontrolled, fluctuations in the influent with seasonal and other 
changes in farm operation. Sampling and measurement errors are also likely on particle rich manure samples. Such fluctuations are reduced through the AD reactor, as expected. The inlet fluctuations are considered noise, so the inflow concentrations are therefore smoothened by median values, floating by the amount of samples indicated after each property, for $\mathrm{NH}_{4}-\mathrm{N}(20)$, COD (6), $\mathrm{COD}_{\mathrm{S}}(4)$, acetate (20), propionate (20) and butyrate (20).

Table 6. Substrate inflow content to the AD reactor in the simulation.

\begin{tabular}{|c|c|c|c|}
\hline $\begin{array}{l}\text { Para } \\
\text { meter }\end{array}$ & Content & Formula & $\begin{array}{l}\text { Denominat } \\
\text { ion }\end{array}$ \\
\hline X_c & composite & 0 & $\mathrm{~g} \mathrm{COD} \mathrm{L}^{-1}$ \\
\hline X_pr & protein & $\begin{array}{c}\text { f_pr*0.11* } \\
\left(\mathrm{COD}_{\mathrm{T}}-\mathrm{COD}_{\mathrm{S}}\right)\end{array}$ & $\mathrm{g} \mathrm{COD} \mathrm{L}^{-1}$ \\
\hline X_li & lipid & $\begin{array}{c}\text { f_li*0.11* } \\
\left(\mathrm{COD}_{\mathrm{T}}-\mathrm{COD}_{\mathrm{S}}\right)\end{array}$ & $\mathrm{g} \mathrm{COD} \mathrm{L}^{-1}$ \\
\hline X_ch & $\begin{array}{l}\text { carbo- } \\
\text { hydrates }\end{array}$ & $\begin{array}{c}\text { f_ch*0.11* } \\
\left(\mathrm{COD}_{\mathrm{T}}-\mathrm{COD}_{\mathrm{S}}\right)\end{array}$ & $\mathrm{g} \mathrm{COD} \mathrm{L}^{-1}$ \\
\hline X_I & solid inert & $\begin{array}{c}0.86^{*} \\
\left(\mathrm{COD}_{\mathrm{T}}-\mathrm{COD}_{\mathrm{S}}\right)\end{array}$ & $\mathrm{g} \mathrm{COD} \mathrm{L}^{-1}$ \\
\hline S_I & $\begin{array}{l}\text { soluble } \\
\text { inert (from } \\
\text { solid) }\end{array}$ & $\begin{array}{c}0.03 * \\
\left(\mathrm{COD}_{\mathrm{T}}-\mathrm{COD}_{\mathrm{S}}\right)\end{array}$ & $\mathrm{g} \mathrm{COD} \mathrm{L}^{-1}$ \\
\hline $\mathrm{COD}_{\mathrm{T}}$ & total & $50.6 \pm 2$ & $\mathrm{~g} \mathrm{COD} \mathrm{L}^{-1}$ \\
\hline $\mathrm{COD}_{\mathrm{S}}$ & soluble & $13.9 \pm 2$ & $\mathrm{~g} \mathrm{COD} \mathrm{L}^{-1}$ \\
\hline S_I & $\begin{array}{l}\text { soluble } \\
\text { inert (from } \\
\text { liquid) }\end{array}$ & $\begin{array}{c}0.1^{*} \\
\left(\mathrm{CODs}-\mathrm{COD}_{\mathrm{VFA}}\right)\end{array}$ & $\mathrm{g} \mathrm{COD} \mathrm{L}^{-1}$ \\
\hline S_su & sugar & $\begin{array}{c}0.18 * f+c h * \\
\left(\mathrm{CODs}-\mathrm{COD}_{\mathrm{VFA}}\right)\end{array}$ & $\mathrm{g} \mathrm{COD} \mathrm{L}^{-1}$ \\
\hline S_aa & $\begin{array}{c}\text { amino } \\
\text { acids }\end{array}$ & $\begin{array}{c}0.18 * f \_p r * \\
\left(\mathrm{COD}_{\mathrm{s}}-\mathrm{COD}{ }_{\mathrm{VFA}}\right)\end{array}$ & $\mathrm{g} \mathrm{COD} \mathrm{L}^{-1}$ \\
\hline S_fa & $\begin{array}{l}\text { long chain } \\
\text { fatty acids }\end{array}$ & $\begin{array}{c}0.18 * f \_l i * \\
\left(\mathrm{COD}_{\mathrm{S}}-\mathrm{COD}{ }_{\mathrm{VFA}}\right)\end{array}$ & $\mathrm{g} \mathrm{COD} \mathrm{L}^{-1}$ \\
\hline S_ac & acetic acid & $3.3-3.6$ & $\mathrm{~g} \mathrm{COD} \mathrm{L}^{-1}$ \\
\hline S_pro & $\begin{array}{l}\text { propionic } \\
\text { acid }\end{array}$ & $1.44-1.50$ & $\mathrm{~g} \mathrm{COD} \mathrm{L}^{-1}$ \\
\hline S_bu & $\begin{array}{l}\text { butyric } \\
\text { acid }\end{array}$ & $0.64-0.65$ & $\mathrm{~g} \mathrm{COD} \mathrm{L}^{-1}$ \\
\hline S_IC & $\mathrm{HNO}_{3}{ }^{-}$ & 0.058 & $\mathrm{M}$ \\
\hline S_IN & $\begin{array}{c}\mathrm{NH}_{4}+ \\
\mathrm{NH}_{3}\end{array}$ & $0.07 \pm 0.001$ & $\mathrm{M}$ \\
\hline
\end{tabular}

The reactor was started more than two years before the test period used here. Simulations of a preliminary period (340 days before the results presented here) were used to adjust $\mathrm{pH}$ and $\mathrm{CO}_{2}$ concentration of the biogas and thereby establish model steady state conditions that correspond to that observed at what is defined as time zero in this study (Fig. 5 and 6). The $\mathrm{CO}_{2}$ concentration in the biogas was adjusted by adding a constant inflow substrate $\mathrm{HCO}_{3}$ level (Table 6). The modeled effluent $\mathrm{pH}$ level was forced to match measured values by adjusting the addition of a constant concentration of ions in the inflow substrate. The active reactor biomass concentrations were also tuned to match steady state performance, found to add up to a level below $10 \mathrm{~g} \mathrm{COD}$ $\mathrm{L}^{-1}$ reactor. This is well below the upper limit of $40 \mathrm{~g}$ $\mathrm{COD} \mathrm{L}^{-1}$ reactor for sludge bed AD (Kleerebezem et al., 2006).
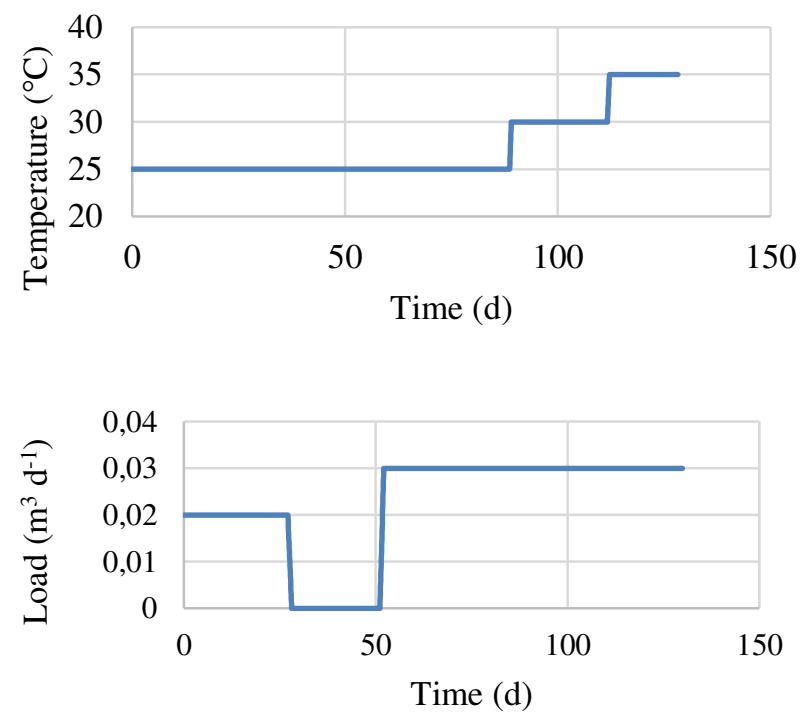

Figure 4. Temperature $\left({ }^{\circ} \mathrm{C}\right)$ and load $\left(\mathrm{m}^{3} \mathrm{~d}^{-1}\right)$ during the experiment.

\subsection{Simulation of $\mathrm{AD}$ reactor}

Sludge retention time (SRT), a key factor in sludge bed $\mathrm{AD}$ processes is evaluated and quantified first to have a SRT calibrated model to investigate temperature effects next.

\subsubsection{Sludge retention time}

The process simulation is observed to be highly dependent on SRT, a parameter that is unknown and uncontrolled in most sludge bed reactors such as tested here. The simulated gas production has a good fit to the experimental values (Fig. 5 A) independent of SRT modelling approach at steady state. The models ability to predict process changes, however, was quite different depending on SRT. SRT has the largest effect on the effluent acetate concentration, with SRT calculated from tres_X $=20$ being closest to the experimental values. The recommended way of simulating SRT using tres_x = 40 (Batstone et al., 2002) has the lowest fit to the experimental values for biogas production but good fit to the acetate concentration. The observation that SRT influence acetate, the reactant for most of the methane production, especially, suggests that 
methanogenesis can be especially sensitive to load transitions and SRT.

SRT is calculated using tres_x $=15$, since it gave the best correlations, for the remaining simulations to evaluate the impact of the various temperature corrected kinetic constants. A lower tres_x, implying lower SRT than that proposed by Batstone et al. (2002) seem reasonable for the present case since HRT was higher than typical for sludge bed AD.
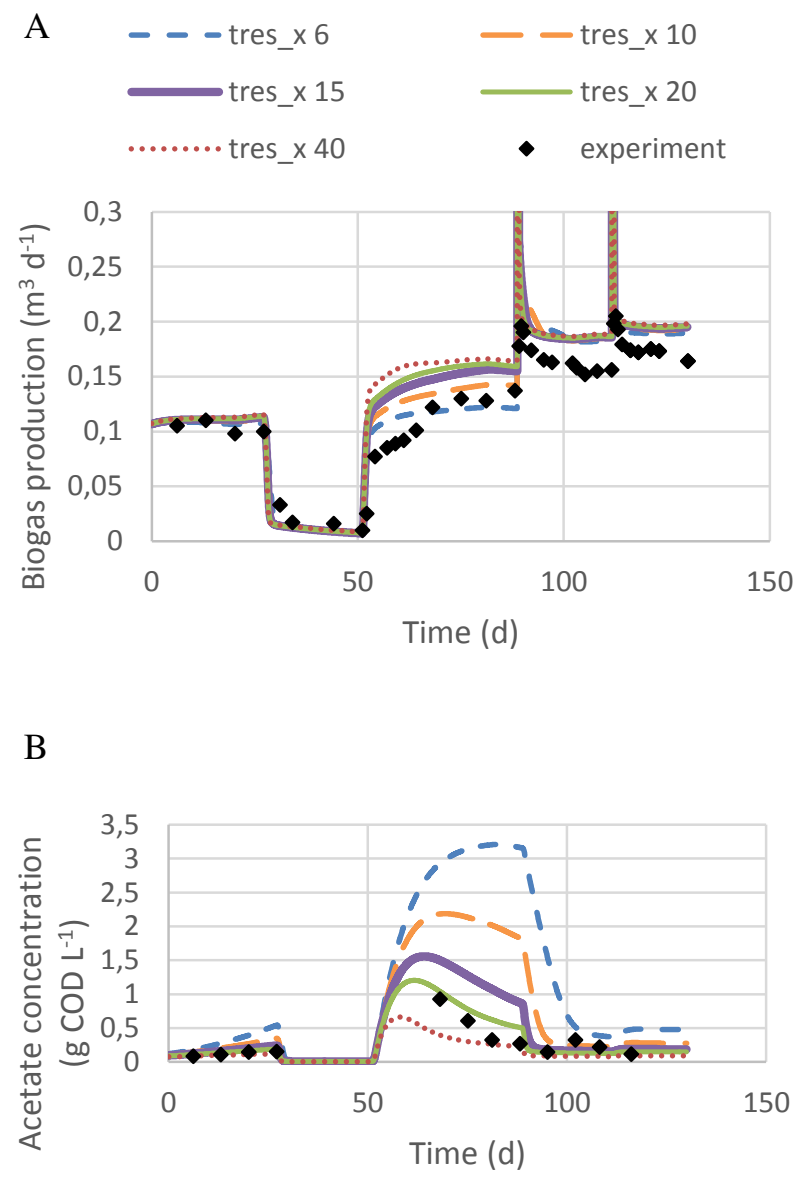

Figure 5. Biogas production rate (A) and effluent acetate concentrations (B) using temperature dependency from Henze and Harremoës (1983). Experimental (diamond) and simulated (lines).

\subsubsection{Temperature effects}

The simulated biogas production and effluent concentrations (Fig. 6) for the various temperature models shows good fit to the measured values. The various temperature effect parameters (Donoso-Bravo et al., 2009; Rebac et al., 1995; Henze and Harremoës, 1983) differ most in simulating acetate concentrations, but less on the overall biogas production rate.

The simulated transient peaks in biogas production following temperature increases are in the same range as observed (Fig 6). Peak shape depends, however, on numeric also: Step size in the simulation below 0.001 day gives reasonable fit (Fig. 6). Larger model numerical step size overestimates this initial peak. The experimental temperature steps lasted for 0.4 and 0.5 days from 25 to $30^{\circ} \mathrm{C}$ and 30 to $35^{\circ} \mathrm{C}$, respectively.

The three simulations " $H$ ", " $D$ " and " $R$ " gave the same biogas production except for " $\mathrm{H}$ " at $30{ }^{\circ} \mathrm{C}$ which coincidence with the original ADM1 model. The original model gave higher biogas production at both 25 ${ }^{\circ} \mathrm{C}$ and $30{ }^{\circ} \mathrm{C}$ but similar to the others at $35{ }^{\circ} \mathrm{C}$ as expected (Fig. 6).
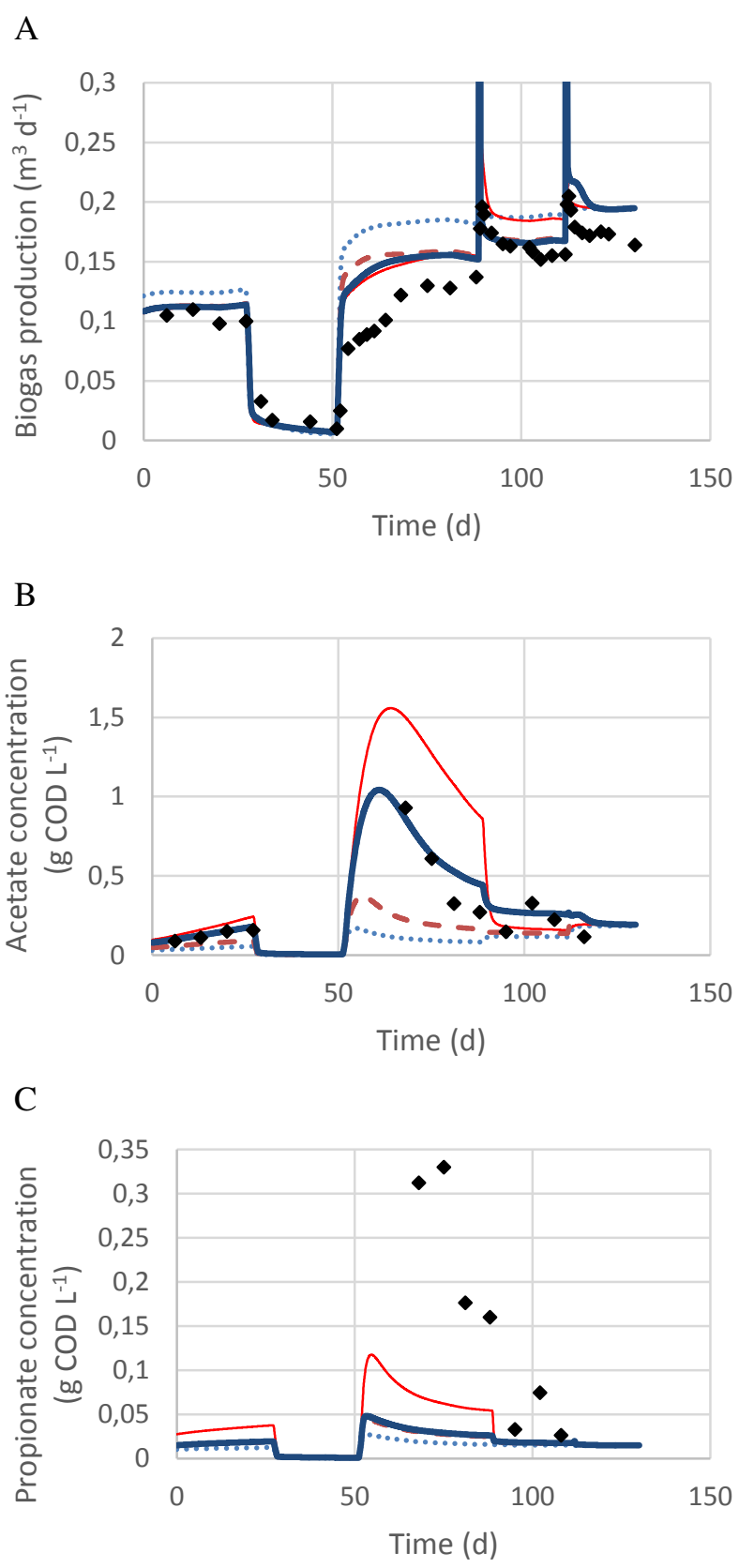

Figure 6. Biogas production rate (A) and effluent acetic (B) and propionic (C) concentration values temperature dependency using original model, Rebac et al. (1995), Donoso-Bravo et al. (2009), Henze and Harremoës (1983) with tres_x $=15 \mathrm{~d}$. Experimental $(\diamond)$ and simulated (lines); original ${ }^{\text {sass }}, \mathrm{D}-\cdots--\mathrm{H} \longrightarrow, \mathrm{R}-$ 
The biogas production, relative to $35{ }^{\circ} \mathrm{C}$, from simulation and experimentally (Table 7) shows that the simulated relative temperature change for " $\mathrm{H}$ " is less affected by temperature than the published biogas production temperature effect used to adjust the kinetic factors (Table 2). This approach with the same temperature factor on each biochemical reaction is however better than the original model, but with less accuracy than using individually temperature effects for each reaction as for " $R$ ".

Table 7. Simulation and experimental results on the temperature effect on biogas production rate.

\begin{tabular}{|c|c|c|c|}
\hline Model & $25{ }^{\circ} \mathrm{C}$ & $30{ }^{\circ} \mathrm{C}$ & $35^{\circ} \mathrm{C}$ \\
\hline $\mathrm{R}$ & 0.79 & 0.85 & 1 \\
\hline $\mathrm{D}$ & 0.81 & 0.86 & 1 \\
\hline $\mathrm{H}$ & 0.80 & 0.95 & 1 \\
\hline Original model & 0.95 & 0.97 & 1 \\
\hline AD experiment & 0.77 & 0.92 & 1 \\
\hline
\end{tabular}

The tested temperature model parameters using the simulation " $\mathrm{R}$ " is predicting the key intermediate, acetate, best. Significant deviations are only found in the simulations of the intermediate product propionate (Fig. 6) with elevated propionate following the load increase. The predictions are less than half of that observed. Note, however, that these levels are low and close to detection limit for propionate. Simulated overall soluble and particulate organic carbon removal and $\mathrm{pH}$ are close to measured values.

The original ADM1 model with only temperature correction for physio-chemical reactions did not simulate the observed temperature effects as well as the new version made here to also include temperature effects on the bio-reactions. It did however predict the transient gas production peak as well as the extended model, implying that this peak has a physical explanation. It is explained by reduced solubility of gasses with increased temperature causing gas release.

The elevated transient acetate suggests that methanogenesis is the rate-limiting step of the process investigated here, but the results are not conclusive except during the transient response to the step load increase (Fig. 5 - 6). It is normally either the disintegration, hydrolysis, degradation of propionic acid or the methanogenesis that is the limiting $\mathrm{AD}$ reaction (Batstone et al., 2002). The temperature effects on biogas production rate reported by Henze and Harremoës, (1983) may indicate hydrolysis as the ratelimiting step and not the methanogenesis for substrates with high particulates content (such as is the case in manure). The relatively small fraction of particles degraded in our experiment may however change this, possibly making methanogenesis the rate limiting process step. This analysis does, therefore, not revealed which biochemical step is rate-limiting during the various phases of the experiment. It can, however, be argued that it is not important to know which step is rate limiting as long as appropriate temperature corrections are applied on the kinetic parameters of all the potentially rate-limiting steps. The reasonably good fit with experimental observations supports this claim.

\section{Conclusion}

The calibrated model, using recommended ADM1 parameters with standard temperature effect models, yields good fit of simulated and measured biogas production. Simulated overall soluble and particulate organic carbon removal, $\mathrm{pH}$ and intermediate products accumulation are also close to measured values. The main deviations between measured and modeled values, observed in transient acetate accumulations, were sensitive both to sludge retention time (SRT) and temperature effect modeling. Temperature effects on microbial substrate uptake rate kinetics accounts for the observed steady state gas generation levels.

Implementing individual temperature effects for each biochemical reaction gave the best fit for both biogas production and effluent acetate concentration. The original ADM1 model did not simulate the observed temperature effect as well as the modified models. All the modified models confirmed the experimental observation that temperature has a moderate influence on steady state biogas production in sludge bed AD (1.6 $\%$ reduced production per degree at $35-30{ }^{\circ} \mathrm{C}$ and 3.4 $\%$ per degree at $30-25^{\circ} \mathrm{C}$ ). It is not revealed which biochemical step is rate-limiting but that seems irrelevant in ADM1 simulations.

The influence of temperature on steady state biogas production in the sludge bed $\mathrm{AD}$ was predictable using standard modeling parameters and moderate $(1.6 \%$ per degree at $30-35{ }^{\circ} \mathrm{C}$ and $3.4 \%$ per degree at $25-30$ $\left.{ }^{\circ} \mathrm{C}\right)$. This imply that the net energy gain can peak at $\mathrm{T}<$ $35^{\circ} \mathrm{C}$ in some cases and that such maxima can be found by the temperature extended ADM1.

\section{Acknowledgements}

The project was supported by the Norwegian Agricultural Agency, Innovation Norway, The Research Council of Norway, Ministry of Education and Research and Telemark University College. The authors wish to thank farmer Knut Vasdal for the good cooperation in carrying out the experiment and Associate Professor Finn Haugen for the automatic process monitoring and control.

\section{References}

Banik, G., Viraraghavan, T., Dague, R. (1998). Low temperature effects on anaerobic microbial kinetic 
parameters. Environmental Technology, 19(5), 503512.

Batstone, D., Keller, J., Angelidaki, I., Kalyuzhnyi, S., Pavlostathis, S., Rozzi, A., . . Vavilin, V. (2002). Anaerobic Digestion Model No. 1 (ADM1). Tech. rep., IWA Publishing.

Bergland, W., Dinamarca, C., Bakke, R. (2014). Efficient biogas production from the liquid fraction of diary manure. Renewable Energy \& Power Quality Journal (RE\&PQJ), 12.

Bergland, W., Dinamarca, C., Toradzadegan, M., Nordgård, A., Bakke, I., Bakke, R. (2015). High rate manure supernatant digestion. Water Research, 76, $1-9$.

Donoso-Bravo, A., Retamal, C., Carballa, M., RuizFilippi, G., Chamy, R. (2009). Influence of temperature on the hydrolysis, acidogenesis and methanogenesis in mesophilic anaerobic digestion: parameter identification and modeling application. Water Science and Technology, 60(1), 9-17.

Grant, S., Lin, K. (1995). Effects of temperature and organic loading on the performance of upflow anaerobic sludge blanket reactors. Canadian Journal of Civil Engineering, 22(1), 143-149.

Hafner, S., Bisogni, J. (2009). Modeling of ammonia speciation in anaerobic digesters. Water Research, 43(17), 4105-4114.

Haugen, F., Bakke, R., Lie, B. (2013). Adapting Dynamic Mathematical Models to a Pilot Anaerobic Digestion Reactor. Modeling, Identification and Control, 34(2), 35-54.

Henze, M., Harremoes, P. (1983). Anaerobic treatment of wastewater in fixed film reactors - A litterature review. Water Science and Technology, 15(8-9), 1101.

Hinshelwood, C. (1947). The Chemical Kinetics of the Bacterial Cell. London: Oxford University Press.

Kettunen, R., Rintala, J. (1997). The effect of low temperature (5-29 degrees $\mathrm{C}$ ) and adaptation on the methanogenic activity of biomass. Applied Microbiology and Biotechnology, 48(4), 570-576.

Kleerebezem, R., van Loosdrecht, M. (2006). Critical analysis of some concepts proposed in ADM1. Water Science and Technology, 54(4), 51-57.

Lin, C., Noike, T., Sato, K., Matsumoto, J. (1987). Temperature characteristics of the methanogenesis process in anaerobic-digestion. Water Science and Technology, 19(1-2), 299-310.

Monod, J. (1949). The Growth of Bacterial Cultures. Annual Review of Microbiology, 3, 371-394.

Møller, H., Sommer, S., Ahring, B. (2004). Methane productivity of manure, straw and solid fractions of manure. Biomass \& Bioenergy, 26(5), 485-495.
Pavlostathis, S., Giraldo-Gomez, E. (1991). Kinetics of anaerobic treatment: A critical review. Critical Reviews in Environmental Control, 21(5-6), 411490.

Rebac, S., Ruskova, J., Gerbens, S., Vanlier, J., Stams, A., Lettinga, G. (1995). High-rate anaerobic treatment of waste-water under psychrophilic conditions. Journal of Fermentation and Bioengineering, 80(5), 499-506.

Saravanan, V., Hemachandran, B., Raj, A., Sundaram, S. (2000). Liquid phase volumetric mass transfer coefficient in dairy effluent stream. Bioprocess Engineering, 23(2), 175-176.

Vavilin, V., Lokshina, L., Rytov, S., Kotsyurbenko, O., Nozhevnikova, A., Parshina, S. (1997). Modelling methanogenesis during anaerobic conversion of complex organic matter at low temperatures. Water Science and Technology, 36(6-7), 531-538.

Veeken, A., Hamelers, B. (1999). Effect of temperature on hydrolysis rates of selected biowaste components. Bioresource Technology, 69(3), 249-254. 